Edunomika - Vol. 01, No. 02 (Agustus 2017)

\title{
UPAYA MENINGKATKAN PRESTASI BELAJAR SEJARAH MELALUI STRATEGI COOPERATIVE LEARNING TEKNIK JIGSAW SISWA KELAS XI IPS SMA NEGERI 1 TAWANGSARI SEMESTER 1 TAHUN PELAJARAN 2017/2018
}

\author{
Suyadi \\ SMA Negeri 1 Tawangsari, Sukoharjo, Jawa Tengah \\ Email: suyadi_18@yahoo.com
}

\begin{abstract}
Abstrak: Penelitian tindakan kelas (PTK) dengan judul Upaya Meningkatkan Prestasi Belajar Sejarah Melalui Strategi Cooperative Learning Teknik Jigsaw Siswa Kelas XI IPS SMA Negeri 1 Tawangsari Semester 1 Tahun Pelajaran 2017/2018 bertujuan untuk meningkatkan minat, keaktifan dan prestasi belajar peserta didik terhadap mata pelajaran sejarah khususnya materi perkembangan masyarakat dan kebudayaan di Indonesia yang bercorak Islam. Penelitian ini dilaksanakan di kelas XI IPS SMA Negeri 1 Tawangsari Sukoharjo. Penelitian dilakukan dalam dua siklus yang masing-masing siklus terdiri dari perencanaan, pelaksanaan, pengamatan, dan refleksi. Sumber data penelitian meliputi: informan, tempat dan peristiwa, dan dokumen. Data dikumpulkan dengan menggunakan teknik observasi langsung, tes dan mencatat dokumen. Hasil penelitian ini menyimpulkan bahwa penerapan strategi pembelajaran kooperatif (cooperative learning) teknik jigsaw dapat meningkatkan minat, keaktifan dan prestasi belajar siswa mata pelajaran sejarah dari rata-rata nilai 75,44 dengan ketuntasan belajar 79,41\% pada siklus I menjadi 79,56 dengan ketuntasan belajar 97,06 pada siklus II.
\end{abstract}

Kata kunci: prestasi belajar, strategi cooperative learning, teknik jigsaw

Abstract: Classroom action research (PTK) with the title Efforts to Increase Learning Achievement History Through Cooperative Learning Strategy Jigsaw Student Class XI IPS SMA Negeri 1 Tawangsari Semester 1 Year Lesson 2017/2018 aims to increase interest, liveliness and learning achievement of learners of subjects history especially the material development of society and culture in Indonesia which is patterned Islam. This research was conducted in class XI IPS SMA Negeri 1 Tawangsari Sukoharjo. The study was conducted in two cycles, each cycle consisting of planning, implementation, observation, and reflection. Sources of research data include: informants, places and events, and documents. Data were collected using direct observation techniques, tests and document records. The result of this research concludes that the application of cooperative learning strategy of jigsaw technique can increase interest, activity and learning achievement of students of history subject from average value 75,44 with learning completeness $79,41 \%$ in cycle I to 79,56 with mastery learning 97.06 on cycle II.

Keywords: learning achievement, cooperative learning strategy, jigsaw technique

\section{PENDAHULUAN}

Pendidikan nasional bertujuan untuk mencerdaskan kehidupan bangsa dan mengembangkan manusia Indonesia seutuhnya. Kondisi yang seutuhnya belum bisa terjawab oleh para guru bahkan Pendidikan Nasional. Saat ini Pendidikan Nasional menghadapi berbagai permasalahan seperti: menurunnya akhlak dan moral peserta didik, pemerataan kesempatan belajar, rendahnya efisiensi internal sistem pendidikan, manajemen 
pendidikan yang tidak sejalan dengan pembangunan nasional, dan sumber daya yang belum profesional (Mulyasa, 2002:4).

Dengan adanya pendidikan, maka akan timbul dalam diri seseorang untuk berlombalomba dan memotivasi diri kita untuk lebih baik dalam segala aspek kehidupan. Keberhasilan pendidikan di sekolah hakikatnya merupakan tanggung jawab semua pihak, pemerintah, masyarakat, dan sekolah terutama guru dan kepala sekolah. Kepala sekolah berperan sebagai manajer sedangkan guru berperan dalam melaksanakan pembelajaran bersama peserta didik di dalam kelas. Sebagaimana dikemukakan Sopandi (1992:23) kehadiran guru sebagai sosok di depan kelas keberadaannya tidak dapat digantikan oleh media pembelajaran secanggih apapun.

Keberhasilan mencapai tujuan pendidikan dapat dilakukan dengan peningkatan prestasi belajar peserta didik melalui kegiatan Proses Belajar Mengajar (PBM). Menurut Lie (2002:4) menjelaskan bahwa Proses pembelajaran yang menggunakan metode satu arah ternyata justru menumpulkan potensi peserta didik.

Berdasarkan ulangan harian ke-1 pada materi kerajaan-kerajaan maritim Indonesia pada masa Islam, di kelas XI IPS 1, SMA Negeri 1 Tawangsari mengindikasikan bahwa prestasi belajar peserta didik masih rendah. Rata-rata nilai ulangan harian ke-1 pada mata pelajaran Sejarah tersebut adalah 72,35 dan belum mencapai ketuntasan belajar minimal (KKM) yang ditetapkan yakni 75 dengan ketuntasan belajar $68 \%$.

Salah satu upaya perlu dilakukan untuk mengatasi permasalahan rendahnya prestasi belajar dengan penerapan strategi pembelajaran cooperative learning teknik jigsaw. Berdasarkan hal-hal tersebut, ditindak lanjuti penelitian tindakan kelas, dengan judul : Upaya Meningkatkan Prestasi Belajar Sejarah melalui Strategi Cooperative Learning Teknik Jigsaw Siswa Kelas XI IPS SMA Negeri 1 Tawangsari Semester 1 Tahun Pelajaran 2017/2018.

\section{KAJIAN PUSTAKA \\ Prestasi Belajar}

Belajar berarti usaha mengubah tingkah laku. Jadi belajar akan membawa suatu perubahan pada individu-individu pebelajar (Sardiman, 1997:18). Sedangkan Hamalik (1986) menjelaskan bahwa belajar adalah modifikasi atau memperteguh kelakuan melalui pengalaman. Belajar bukan hanya sekadar mengingat tetapi mengalami yang menghasilkan suatu perubahan tingkah laku. Belajar merupakan suatu proses, suatu kegiatan dan bukan suatu hasil atau tujuan. Sedangkan Hilgard (dalam Nasution, 1986) mengemukakan bahwa belajar adalah proses yang melahirkan atau mengubah suatu kegiatan melalui jalan latihan (apakah dalam laboratorium atau dalam lingkungan alamiah) yang dibedakan dari perubahan-perubahan oleh faktor-faktor yang tidak termasuk latihan.

Prestasi belajar atau hasil belajar menurut Sudjana (1991) adalah "beragam kemampuan yang dimiliki siswa setelah ia menerima pengalaman belajarnya” (hal. 22). Selanjutnya Dewanto mengemukakan bahwa prestasi belajar merupakan hasil pengalaman belajar. Hasil pengalaman belajar merupakan macam-macam kemampuan, keterampilan dan 
pengetahuan yang dimiliki oleh siswa setelah mengikuti suatu kegiatan, latihan, pendidikan atau proses belajar mengajar (Dewanto, 1995: 9). Sedangkan Tobroni (2007:120) mengemukakan bahwa prestasi adalah cita-cita yang diwujudkan dalam kenyataan. Secara akademik prestasi diartikan sebagai hasil pelajaran yang diperoleh dari kegiatan belajar di sekolah yang bersifat kognitif dan biasanya ditentukan melalui pengukuran dan penilaian.

Dari batasan tersebut dapat ditarik suatu kesimpulan bahwa prestasi belajar adalah hasil pengukuran terhadap peserta didik yang meliputi aspek kognitif, afektif, dan psikomor, setelah mengikuti proses belajar, yang diukur dengan menggunakan instrumen tes atau instrumen lain yang relevan.

\section{Pembelajaran Cooperative Learning}

Pembelajaran Cooperative Learning atau pembelajaran kooperatif tujuannya untuk meningkatkan kerjasama antar siswa, membentuk hubungan positif, mengembangkan rasa percaya diri, serta meningkatkan hasil belajar melalui aktivitas kelompok. Pembelajaran kooperatif memungkinkan semua siswa dapat menguasai materi pada tingkat penguasaan yang relatif sama atau sejajar.

Materi yang sesuai disajikan dengan menggunakan model pembelajaran kooperatif adalah materi-materi yang menuntut pemahaman tinggi terhadap nilai, konsep, atau prinsip, serta masalah-masalah aktual yang terjadi di masyarakat. Roger dan Johnson (dalam Lie, 2002) mengemukakan bahwa tidak seumur kerja kelompok bias dianggap Cooperative Learning. Untuk mencapai hasil maksimal, pembelajaran Cooperative Learning memiliki lima unsur, antara lain: (1) saling ketergantungan positif, (2) tanggung jawab perseorangan, (3) tatap muka, (4) komunikasi antar anggota, (5) evaluasi proses kelompok

Ada empat macam model pembelajaran kooperatif yang dikemukakan oleh Arends (dalam Lie, 2002), yaitu; (1) Student Teams Achievement Division (STAD), (2) Group Investigation, (3) Jigsaw, dan (4) Structural Approach.

Teknik pembelajaran Jigsaw dikembangkan oleh Aronson et al. sebagai metode Cooperative Learning. Teknik ini dapat digunakan dalam beberapa mata pelajaran, seperti Sejarah, IPS, Matematika, Agama dan Bahasa (Lie, 2002: 68).

Pembelajaran kooperatif teknik jigsaw adalah satu tipe pembelajaran kooperatif yang terdiri dari beberapa orang anggota dalam satu kelompok yang bertanggungjawab atas penguasaan materi belajar dan mampu mengajarkan bagian tersebut kepada anggota lain dalam kelompoknya (Nur, 2005:63). Banyaknya anggota kelompok dalam pembelajaran kooperatif tipe Jigsaw biasanya terdiri dari $4-6$ orang.

\section{Mata Pelajaran Sejarah}

Secara etimologis kata sejarah berasal dari bahasa Arab syajarah yang berarti pohon dan syajarah an-nasab yang bermakna pohon silsilah (Kuntowijoyo, 1995: 12). Istilah lain yang digunakan masyarakat Indonesia untuk mengacu pengertian sejarah seperti riwayat, hikayat, tambo, babad dan tutui teteek (Depdiknas, 2004: 34). 
Kartodirdjo (1992:14) berpendapat bahwa sejarah dalam arti subjektif adalah suatu konstruk. Konsstruk merupakan bangunan yang disusun penulis sebagai suatu uraian atau cerita. Sedangkan sejarah dalam arti objektif menunjuk pada peristiwa itu sendiri yang merupakan proses sejarah dalam aktualitasnya. Pengertian sejarah sebagai bagian dari kurikulum adalah mata pelajaran yang menanamkan nilai-nilai proses perubahan dan perkembangan masyarakat Indonesia dan dunia dari masa lampau hingga masa kini (Depdiknas, 2003: 6).

Pengajaran sejarah di sekolah bertujuan agar peserta didik memperoleh kemampuan berpikir historis dan menumbuhkan jati diri bangsa di tengah-tengah kehidupan masyarakat dunia (Depdiknas, 2003:4). Pembelajaran sejarah mempunyai fungsi untuk menyadarkan peserta didik akan adanya proses perubahan dan perkembangan masyarakat dalam dimensi waktu dan untuk menjelaskan jati diri bangsa di masa lalu, masa kini, dan masa depan.

Ciri utama sejarah adalah masa lampau manusia. Sebagai ilmu, sejarah adalah ilmu tentang waktu, atau sejarah adalah ilmu yang merekonstruksi masa lampau. Sejarah merupakan ilmu empiris yang menjadikan waktu manusia atau manusia dalam waktu sebagai objek (Kuntowijoyo, 1995:14). Karakteristik sejarah selanjutnya adalah mengenai perubahan, sejarah pada prinsipnya dapat diartikan sebagai ilmu tentang perubahan dalam konteks waktu yang menyangkut masa lampau manusia.

\section{METODE PENELITIAN}

Penelitian ini merupakan penelitian tindakan kelas (PTK) yang dilakukan dalam dua siklus yang masing-masing terdiri atas empat tahapan, yaitu: 1) perencanaan (planning), 2) pelaksanaan tindakan (action), 3) pengamatan (observation), dan 4) refleksi (reflection).

Dalam penelitian tindakan ini data yang dikumpulkan dan dikaji berupa data kualitatif dan kuantitatif, digali dari beragam sumber data meliputi informan yaitu guru peneliti dan peserta didik siswa kelas XI IPS 1, tempat dan peristiwa kegiatan pembelajaran, dan dokumen berupa silabus, RPP dan daftar nilai. Kemudian data dan informasi dikumpulkan dengan metode 1) Observasi pengamatan dan pencatatan secara sistemik (Rubiyanto, 2009:75. 2) Tes yang ini diberikan di setiap akhir siklus penelitian, 3) Dokumentasi yaitu catatan peristiwa yang sudah berlalu (Sugiyono, 2005: 82).

Teknik pengumpulan data penelitian tindakan kelas ini menggunakan dua teknik yaitu teknik deskriptif kualitatif dan deskriptif komparatif. Dalam penelitian ini peneliti mengambil data-data dari observasi yang dilakukan pada saat pelaksaaan tindakan dari siklus I dan siklus II. Selain itu peneliti mengambil data dari tes yang dilaksanakan oleh siswa di setiap akhir siklus yaitu post test siklus I dan post test siklus II. Kemudian peneliti membandingkan hasil dari kedua siklus tersebut serta disampaikan simpulan sebagai hasil akhir dari penelitian.

\section{HASIL PENELITIAN DAN PEMBAHASAN Hasil Penelitian}


Pada tahap perencanaan perbaikan pembelajaran Siklus I guru membuat persiapan berupa skenario pembelajaran dengan strategi kooperatif (cooperative learning) teknik jigsaw melalui pendekatan saintifik, RPP, instrumen lembar pengamatan, media pembelajaran berupa gambar-gambar, dan jadwal pelaksanaan tindakan.

Pelaksanaan perbaikan pembelajaran yang meliputi kegiatan awal, kegiatan inti, dan kegiatan penutup. Berdasarkan pengamatan dari pelaksanaan pembelajaran diketahui bahwa keaktifan belajar peserta didik hanya $70 \%$, yang lain $30 \%$ bersikap pasif sedang keaktifan dalam diskusi kelompok $80 \%$. Hasil nilai tes formatif peserta didik yang mencapai ketuntasan belajar ada 27 anak (79,41\%), sedangkan 7 anak (20,59\%) nilainya masih di bawah KKM.

Selanjutnya perencanaan perbaikan pembelajaran Siklus II guru kembali membuat persiapan berupa skenario pembelajaran dengan strategi kooperatif (cooperative learning) teknik jigsaw melalui pendekatan saintifik, RPP, instrumen lembar pengamatan, media pembelajaran berupa powerpoint, dan jadwal pelaksanaan tindakan.

Pelaksanaan perbaikan pembelajaran yang meliputi kegiatan awal, kegiatan inti, dan kegiatan penutup. Berdasarkan pengamatan dari pelaksanaan pembelajaran diketahui bahwa keaktifan belajar peserta didik hanya $80 \%$, yang lain $20 \%$ bersikap pasif sedangkan keaktifan dalam diskusi kelompok 95\%. Hasil nilai tes formatif peserta didik yang mencapai ketuntasan belajar ada 33 anak (97,06\%), sedangkan 1anak (2,86\%) nilainya masih di bawah KKM.

\section{PEMBAHASAN}

Berdasarkan uraian hasil penelitian siklus I menunjukkan bahwa peserta didik belum aktif melakukan kegiatan-kegiatan sesuai dengan skenario pembelajaran yang dirancang dalam rencana perbaikan pembelajaran. Hal ini disebabkan guru belum menguasai strategi pembelajaran kooperatif (cooperative learning) teknik jigsaw dan media yang digunakan berkesan seadanya.

Data yang diperoleh dari pengamatan atau observasi menunjukkan aktivitas peserta didik dalam pembelajaran diketahui sebagai berikut: 1) mengikuti pembelajaran secara aktif selama apersepsi hanya 90\%, 2) mendengarkan dan mencatat penjelasan guru $80 \%, 3$ ) antusias menjawab pertanyaan guru menyampaikan pertanyaan 60\%, 4) mengajukan pertanyaan kepada guru 60\%, 5) keaktifan diskusi kelompok 82\%, 6) mempresentasikan laporan hasil diskusi oleh kelompok 80\%,7) memberikan tanggapan dalam presentasi 70\%), 8) mengerjakan dan mengumpulkan tugas laporan hasil diskusi $100 \%$.

Pada pelaksanaan siklus I hasil belajar peserta didik, sebagai berikut: 1) nilai tertinggi 90 yang diraih 1 anak, 2) nilai terendah 65 yang diraih 2 anak, 3) rata-rata kelas 75,44, 4) Peserta didik yang memperoleh nilai $\geq$ KKM 75 ada 27 anak $(79,41 \%)$, sedangkan yang memperoleh nilai di bawah KKM ada 7 anak $(20,59 \%)$. 


\section{Grafik Nilai Pelaksanaan Perbaikan Siklus I}

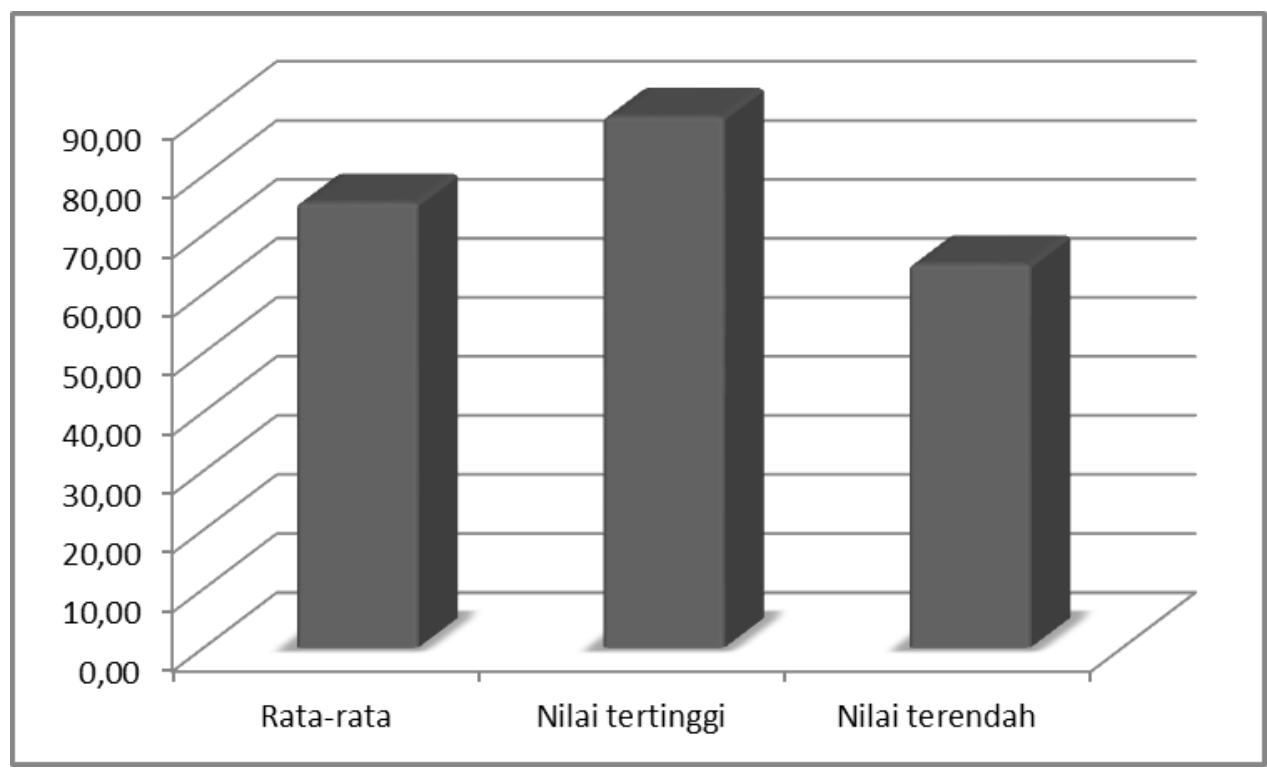

Berdasarkan uraian hasil penelitian siklus II menunjukkan bahwa peserta didik sudah aktif melakukan kegiatan-kegiatan sesuai dengan skenario pembelajaran yang dirancang dalam rencana perbaikan pembelajaran siklus II. Hal ini disebabkan guru sudah menguasai strategi pembelajaran kooperatif (cooperative learning) teknik jigsaw dan guru menambah penggunaan media pembelajaran berbasis komputer berupa bahan presentasi powerpoint.

Data yang diperoleh dari pengamatan atau observasi menunjukkan aktivitas peserta didik dalam pembelajaran diketahui sebagai berikut: 1) mengikuti pembelajaran secara aktif selama apersepsi hanya 100\%, 2) mendengarkan dan mencatat penjelasan guru $100 \%$, 3) antusias menjawab pertanyaan guru menyampaikan pertanyaan $80 \%$, 4) mengajukan pertanyaan kepada guru 80\%, 5) keaktifan diskusi kelompok 95\%, 6) mempresentasikan laporan hasil diskusi oleh kelompok 95\%, 7) memberikan tanggapan dalam presentasi 90\%), 8) mengerjakan dan mengumpulkan tugas laporan hasil diskusi $100 \%$.

Pada pelaksanaan siklus II hasil belajar peserta didik, sebagai berikut: 1) nilai tertinggi 90 yang diraih 3 anak, 2) nilai terendah 70 yang diraih 1 anak, 3) rata-rata kelas $79,56,4)$ Peserta didik yang memperoleh nilai batas KKM dan di atas KKM ada 33 $(97,06 \%)$ anak, sedangkan yang memperoleh nilai di bawah KKM ada $1(2,86)$ anak, 5) persentase ketuntasan belajar peserta didik 97,06\%. 


\section{Grafik Nilai Pelaksanaan Perbaikan Siklus II}

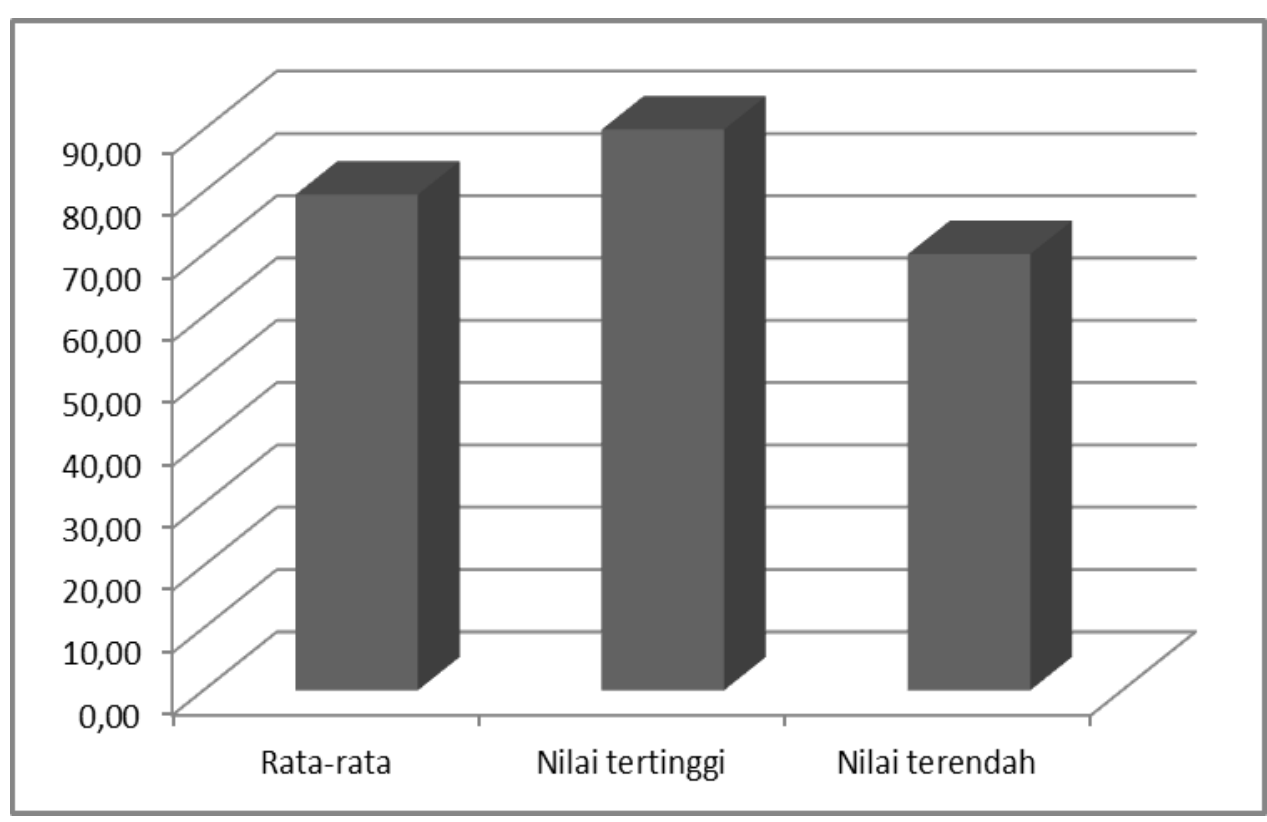

Berdasarkan data di atas, dilihat dari aspek aktivitas peserta didik dan hasil belajar peserta didik kelas kelas XI IPS 1 SMA Negeri 1 Tawangsari, telah meningkat. Dibandingkan dengan kondisi pra siklus dan siklus I pelaksanaan perbaikan pembelajaran siklus II mengalami kenaikan nilai rata-rata 7,21 point dari 72,35 menjadi 79,56.

\section{Grafik Ketuntasan Belajar Pra Siklus, Siklus I, dan II}




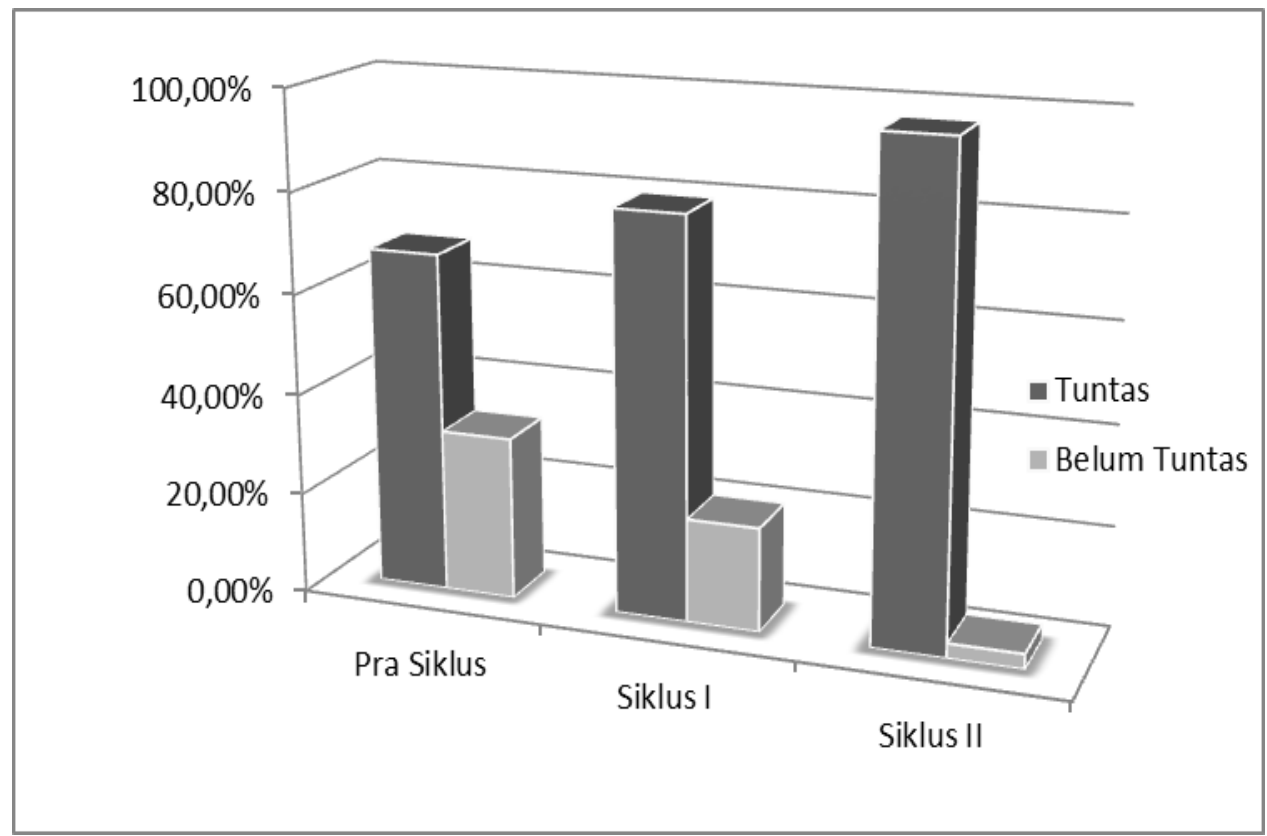

\section{SIMPULAN}

Penelitian tindakan kelas ini dapat disimpulkan bahwa penerapan strategi pembelajaran cooperative learning teknik jigsaw dapat meningkatkan prestasi dan keaktifan belajar siswa. Peningkatan prestasi belajar ditunjukkan dengan persentase ketuntasan $67,65 \%$, siklus 1 nilai rata-rata 75,44 dengan persentase ketuntasan belajar 79,41\%. Pada tahapan siklus 2 nilai rata-rata 79,56 dengan persentase ketuntasan belajar 97,06\%. Peningkatan keaktifan belajar siswa ditunjukkan pada tiap siklus, yakni siklus 1 kategori aktif $80 \%$ dan kurang aktif $20 \%$. Pada tahapan siklus 2 kategori aktif $95 \%$ dan kurang aktif $5 \%$.

Berdasarkan pada simpulan penelitian di atas dapat disarankan, agar guru dapat meningkatkan keaktifan dan prestasi belajar siswa dengan melakukan perbaikan pembelajaran melalui penelitian tindakan kelas. Kemudian guru dapat melaksanakan perbaikan pembelajaran dengan menerapkan berbagai strategi, metode, model pembelajaran yang aktif, inovatif, kreatif, efektif, dan menyenangkan (PAIKEM).

\section{DAFTAR PUSTAKA}

Arikunto, Suharsimi; Suharjono; Suparti. 2008. Penelitian Tindakan Kelas. Jakarta: Bumi Aksara.

Depdiknas. 2003. Kurikulum 2004. Jakarta: Puskur Balitbang Depdiknas. . 2004. Kurikulum 2004. Jakarta: Puskur Balitbang Depdiknas.

Dewanto. 1995. Pengukuran dan Evaluasi Pendidikan. Semarang: IKIP Semarang Press.

Ghazali, A. Syukur. 2002. Metode Pengajaran Sastra dengan Strategi Belajar Kooperatif. Magelang: Indonesia Tera.

Hamalik, Oemar. 1986. Strategi Belajar Mengajar. Bandung: Pustaka Martiana.

Kuntowijoyo. 1995. Pengantar Ilmu Sejarah. Yogyakarta: Aditya Media.

Lie, Anita. 2002. Cooperative Learning. Jakarta: Gramedia Widiasarana Indonesia. 
Mudjiono 2002. Belajar dan Pembelajaran. Jakarta: Rineka Cipta.

Mulyasa, E. 2002. Kurikulum Berbasis Kompetensi, Konsep, Karakteristik, dan Implementasi. Bandung: Remaja Rosdakarya.

Nasution, S. 1986. Didaktik Asas-Asas Mengajar. Bandung: Jemmars.

Nur, Muhammad. 2005. Pembelajaran Kooperatif. Surabaya: Pusat Sains dan Matematika Sekolah UNESA.

Sardiman, A.M. 1997. Interaksi dan Motivasi Belajar Mengajar. Jakarta: Rajawali Press

Sartono Kartodirdjo. 1992. Pendekatan Ilmu Sosial Dalam Metodologi Sejarah. Jakarta: Gramedia

Sopandi. 1992. Peranan Guru dalam Proses Pembelajaran. Jakarta : Depdikbud

Sudjana, Nana. 1991. Penilaian Hasil Proses Belajar Mengajar. Bandung: Remaja Rosdakarya.

Sugiyono. 2005. Metode Penelitian Administrasi. Bandung: Alfabeta

Wardami, I.G.A.K.; Kuswaya Wihardit; Noehi Nasoetion. 2003. Penelitian Tindakan Kelas. Jakarta: Penerbit Universitas Terbuka. 